\title{
Acute adrenal failure as the heralding symptom of primary antiphospholipid syndrome: report of a case and review of the literature
}

\author{
Fabio Presotto, Francesca Fornasini, Corrado Betterle ${ }^{1}$, Giovanni Federspil and Marco Rossato \\ Third Division of Internal Medicine and ${ }^{1}$ Division of Endocrinology, Department of Medical and Surgical Sciences, University of Padua School of Medicine, \\ I-35128, Padua, Italy \\ (Correspondence should be addressed to F Presotto, Department of Medical and Surgical Sciences, Third Division of Internal Medicine, University of Padua \\ Medical School, via Giustiniani 2, I-35128 Padua, Italy; Email: fabio.presotto@unipd.it)
}

\begin{abstract}
Acute adrenal failure is a potentially fatal condition if overlooked. Occasionally, acute adrenal insufficiency may ensue from bilateral adrenal haemorrhage in patients with known antiphospholipid syndrome (APS). APS is characterized by recurrent arterial and venous thrombosis, pregnancy complications and detection of autoantibodies to phospholipids. This syndrome may be associated with non-organ specific diseases (e.g. connective tissue disorders) or with malignancies, but it may also appear in isolated form (primary APS). In a very few cases the heralding manifestation is given by adrenal failure. We report here a 63-year-old man presenting with acute adrenal insufficiency as the opening clinical manifestation of an APS. We also carried out a computer-aided search of the literature to identify all cases of primary adrenal failure as the first-recognized expression of a primary APS, a condition that not so infrequently may be tackled by endocrinologists. 20 patients fulfilled the inclusion criteria. The great majority of them were males $(75 \%)$ with a mean age of 42 years. Abdominal pain was present in 14 patients, followed by fever (13 patients) and hypotension (12 patients). The main morphological findings by computed tomography or magnetic resonance were consistent with bilateral adrenal haemorrhage in 11 patients. Lupus anticoagulant was present in all of the 19 tested patients. Our observations emphasize the importance in the assessment of clotting times, and possibly of antiphospholipid antibodies, in all patients with diagnosis of rapidly progressive adrenal failure and concurrent abdominal pain.
\end{abstract}

European Journal of Endocrinology 153 507-514

\section{Introduction}

Primary adrenal failure (Addison's disease) represents the end stage of a destructive process involving the adrenal cortex. Addison's disease is thought to be a rare disorder, but recent epidemiological studies have reported a rising prevalence in developed countries, being reckoned to be 93-140 per million with an incidence of 4.7-6.2 per million (1). Autoimmune adrenalitis is currently accepted to be the principal cause of adrenal failure, accounting for approximately $80 \%$ of the cases followed by tuberculosis $(\sim 15 \%)$, whereas only $5 \%$ of the cases are related to unusual disorders (2). Among these unusual forms, patients with antiphospholipid syndrome (APS) may show adrenal involvement (3), sometimes in the context of a catastrophic variant of APS (4). Overt Addison's disease is reported in only $0.4 \%$ of patients with ascertained APS (5). Conversely, an APS is diagnosed in less than $0.5 \%$ of all patients with Addison's disease (1 of 350 in our personal series inclusive of both acute and slow-onset adrenal failure).

It is worth noting that hypoadrenalism may be the heralding manifestation of an APS, and that acute primary adrenocortical failure is a life-threatening condition if not recognized promptly. The immunologic hallmark of APS is the detection of circulating antiphospholipid antibodies, which are an expanding group of autoantibodies directed against different phospholipids and phospholipid-associated plasma proteins that have been related to a hypercoagulability state (6). The main autoantigen has been identified in the $\beta_{2}$-glycoprotein I, a protein that binds cardiolipin and other anionic phospholipids, but many other components involved in the coagulation pathway may be recognized by sera of patients with APS $(6,7)$. To fulfil the diagnosis of APS patients have to meet at least one clinical sign (vascular thrombosis or pregnancy complications) and one laboratory criterion (anticardiolipin $\operatorname{IgG}$ or $\operatorname{IgM}$ antibodies, lupus anticoagulant of $\operatorname{IgG}$ or IgM classes 
detected on two or more occasions at least six weeks a part) (6). Lupus anticoagulant antibodies are generally more specific for the APS, whereas anticardiolipin antibodies are more sensitive ((6) and references therein). Although many discrepancies exist between different laboratories and methods for the detection of antiphospholipid antibodies, which are still far from optimal standardization, measurement of activated partial thromboplastin time as the routine phospholipiddependent clotting time is well standardized and may be considered a reliable screening coagulation assay when APS is suspected. Despite lupus anticoagulant antibodies leading to prolongation of clotting times by inhibiting phospholipid-dependent procoagulant pathways in most in vitro assays, in vivo these antibodies promote the inhibition of anticoagulant pathways, favouring thrombosis. Several hypotheses have been formulated to explain why antiphospholipid antibodies yield clinically to thrombosis rather than to bleeding. However, there has been accumulating evidence that antiphospholipid antibodies may recognize the $\beta_{2}$-glycoprotein I bound to the surface of resting endothelial cells, whose activation switches them to a procoagulant and pro-adhesive phenotype $(6,7)$. Consequently, the great majority of clinical signs of APS are related to recurrent venous, arterial or small-vessel thrombosis occurring within any tissue or organ (6). APL antibodies have been mainly described in association with non-organ-specific autoimmune diseases (particularly systemic lupus erythematosus) or malignancies, but also in the absence of any other recognized illness (primary APS, or PAPS) $(6,8)$. The characteristic clinical manifestations of APS are deep-vein thrombosis of the limbs, followed by cerebral arterial thrombosis, recur- rent abortion and late foetal loss. A wide variety of disorders have been described in patients with APS and a detailed description of classical and unusual symptoms has been reported on 1000 patients by a European consortium (5). Among the unusual features of APS, adrenal failure is considered exceptional, but the recognition of adrenal lesions in patients with APS is every increasing and 86 patients with adrenal involvement have been described so far (3). Nevertheless, not all patients with adrenal involvement develop clinical hypoadrenalism. Furthermore, only in a minority of APS patients are the heralding symptoms given by acute adrenal insufficiency.

Here we report a new case of bilateral adrenal haemorrhage as the first-recognized expression of PAPS and review the literature of patients showing Addison's disease as the opening manifestation of the syndrome.

\section{Case report}

In July 2002, a 63-year-old man was admitted to hospital for the occurrence of an abrupt pain to his right flank during a 2-week holiday in a seaside resort. On direct questioning, no blunt abdominal or thoracolumbar traumas were reported. During the diagnostic work-up for the abdominal pain performed in the hospital where he was on holiday, an abdominal computed tomography (CT) scan showed several stones in the gallbladder and enlarged dense masses of about $6 \mathrm{~cm}$ diameter in the left adrenal gland and of $4 \mathrm{~cm}$ in the right (Fig. 1A). Five days later, however, he again experienced abdominal pain at the upper quadrants, with fever and nausea. He was therefore admitted to a surgical ward of the residence hospital with the suspicion of acute colecistitis.

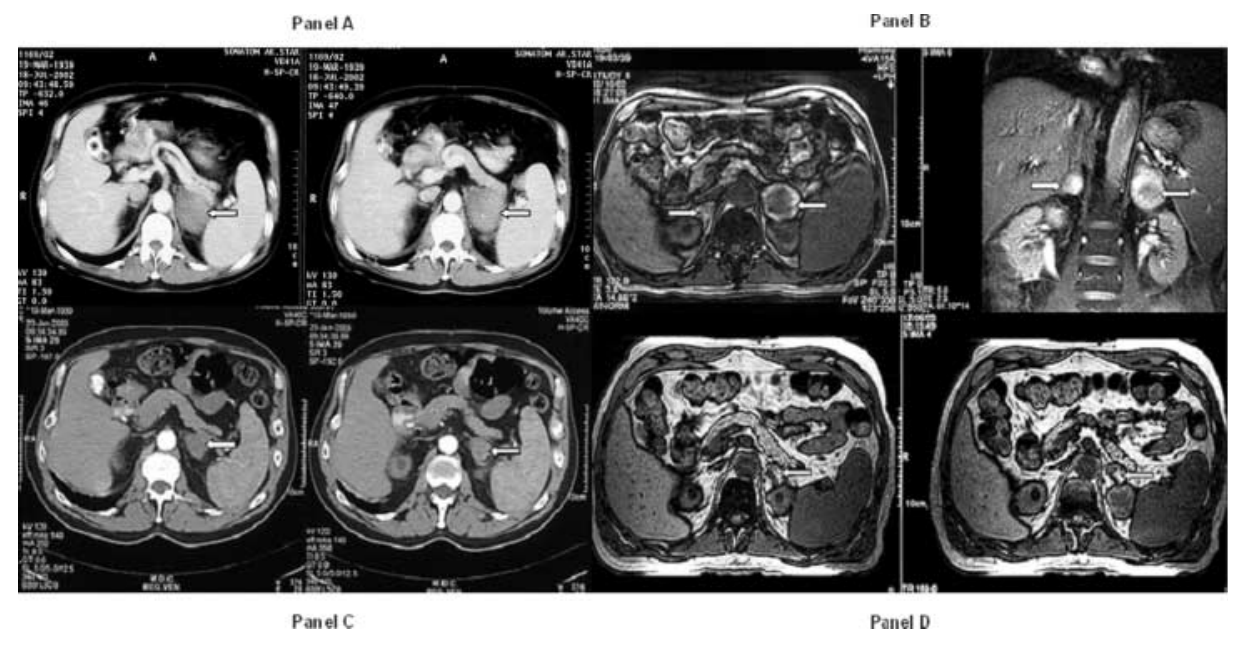

Figure 1 (A, July 2002) CT scans show dense enlargement of left adrenal gland (the right gland is not clearly visible in this section). Some bile stones with a central hypodense core and a mean diameter of about $15 \mathrm{~mm}$ are also visible in the gallbladder. (B, October 2002) NMR shows increased volume in both adrenal glands (left, $4 \mathrm{~cm}$; right, $2 \mathrm{~cm}$ ) with a signal intensity that was low on T1-weighted and peripherally enhanced on T2-weighted imaging consistent with sero-haemorrhagic component. (C, January 2003) CT scans show moderate enlargement of left adrenal gland $(3.5 \mathrm{~cm})$. A gross bile stone is also evident in the gallbladder. (D, June 2003) On NMR, the adrenal glands appear only slightly increased (left, $3 \mathrm{~cm}$; right, $2 \mathrm{~cm}$ ), with enhanced signal on T1-weighted imaging in the left adrenal gland, consistent with haemorrhage. 
Table 1 Summary of haematochemical, endocrine and immunologic findings in the present case with PAPS diagnosed as acute adrenal failure.

\begin{tabular}{|c|c|c|c|}
\hline & Patient & & Normal range \\
\hline \multicolumn{4}{|l|}{ Routine tests (July 2002) } \\
\hline White blood cell count & 9.75 & $4.76^{*}$ & $4.5-11.0 \times 10^{9} / 1$ \\
\hline Red blood cells count & 3.61 & $2.93^{*}$ & $4.7-6.1 \times 10^{12} / /$ \\
\hline Haemoglobin & 108.0 & $106.0^{*}$ & $120-160 \mathrm{~g} / \mathrm{l}$ \\
\hline Haematocrit & 32.7 & & $40-50 \%$ \\
\hline Platelet count & 76.0 & $97.0^{*}$ & $150-350 \times 10^{9} / 1$ \\
\hline Glycaemia & 5.7 & & $3.7-6.1 \mathrm{mM}$ \\
\hline Urea & 15.8 & & $1.8-7.5 \mathrm{mM}$ \\
\hline Creatinine & 195.0 & & $53-115 \mu \mathrm{M}$ \\
\hline Sodium & 131.0 & & $135-145 \mathrm{mM}$ \\
\hline Potassium & 4.3 & & $3.1-4.5 \mathrm{mM}$ \\
\hline Amylase & 61.0 & $68.0^{*}$ & $0-100 \mathrm{U} / \mathrm{l}$ \\
\hline Bilirubin & 16.7 & & $1.7-17.0 \mu \mathrm{mol} / \mathrm{l}$ \\
\hline AST & 39.0 & & $10-45 \mathrm{U} / \mathrm{I}$ \\
\hline ALT & 47.0 & & $10-50 \mathrm{U} / \mathrm{l}$ \\
\hline ALP & 56.0 & & $56-128 \mathrm{U} / \mathrm{l}$ \\
\hline GGT & 57.0 & & $3-65 \mathrm{U} / \mathrm{I}$ \\
\hline $\mathrm{C}$ reactive protein & 22.0 & & $0-5 \mathrm{mg} / \mathrm{l}$ \\
\hline Prothrombin time & 1.1 & & $0.9-1.2$ (INR) \\
\hline Activated partial thromboplastin time & $>120$ & & $23-36 s$ \\
\hline \multicolumn{4}{|l|}{ Haematologic evaluation (August 2002) } \\
\hline Prothrombin time & 1.18 & & $0.9-1.2(\mathrm{INR})$ \\
\hline Activated partial thromboplastin time & $>120$ & & $23-36 s$ \\
\hline Fibrinogen & 8.76 & & $2.0-4.0 \mathrm{~g} / \mathrm{l}$ \\
\hline Fibrin degradation products & 2940 & $5230^{*}$ & $0-500 \mu \mathrm{g} / \mathrm{l}$ \\
\hline AT III & $80 \%$ & & $80-120 \%$ \\
\hline Dilute Russell's viper venom time & 176.0 & & $23-37 s$ \\
\hline Kaolin clotting time & $>220$ & & $65-140 s$ \\
\hline Protein S (activity) & 106.0 & & $70-130 \%$ \\
\hline Protein C (activity) & 121.0 & & $70-130 \%$ \\
\hline \multicolumn{4}{|l|}{ Endocrine evaluation (August 2002) } \\
\hline ACTH 0.800 & 53.0 & & $2-10 \mathrm{pM}$ \\
\hline Cortisol 0.800 & 133.0 & & $198-695 \mathrm{nM}$ \\
\hline Plasma rennin activity (supine) & 0.18 & $3.12^{*}$ & $0.2-3.3 \mu \mathrm{g} / / \mathrm{h}$ \\
\hline Plasma rennin activity (upright) & 0.85 & $8.23^{*}$ & $1.3-5.2 \mu \mathrm{g} / / / \mathrm{h}$ \\
\hline Aldosterone (supine) & 80.0 & $<60.0^{*}$ & $80-280$ pM \\
\hline Aldosterone (upright) & 80.0 & $60.0^{*}$ & $140-800 \mathrm{pM}$ \\
\hline Aldosterone (urine) & 8.0 & $2.0^{*}$ & $8-53 \mathrm{nmol} / 24 \mathrm{~h}$ \\
\hline Dehydroepiandrosterone sulphate & 0.3 & $0.6^{*}$ & $2.2-10.5 \mu \mathrm{M}$ \\
\hline Adrenaline (urine) & 1.0 & & $0-22 \mu \mathrm{g} / 24 \mathrm{~h}$ \\
\hline Noradrenaline (urine) & 24 & & $0-90 \mu \mathrm{g} / 24 \mathrm{~h}$ \\
\hline Thyroid-stimulating hormone & 2.54 & & $0.2-4.5 \mathrm{mU} / \mathrm{l}$ \\
\hline \multicolumn{4}{|l|}{ Autoimmunologic evaluation (August 2002) } \\
\hline Antibodies to cardiolipin (IgG) & 5.2 & $9.0 \dagger$ & $\leq 10 \mathrm{GPL}$ units \\
\hline Antibodies to cardiolipin (IgM) & 61.7 & $46.0 \dagger$ & $\leq 10 \mathrm{MPL}$ units \\
\hline Antibodies to $\beta_{2}$-glycoprotein I (IgG) & 3.0 & $3.0 \dagger$ & $\leq 10 \mathrm{GPL}$ units \\
\hline Antibodies to $\beta_{2}$-glycoprotein I (IgM) & 38.0 & $21.0 \dagger$ & $\leq 10 \mathrm{GPL}$ units \\
\hline Lupus anticoagulant (LAC) & 3.69 & & $<1.2$ \\
\hline Antibodies to adrenal cortex & Negative & & Negative \\
\hline Antibodies to 21-hydroxylase & Negative & & Negative \\
\hline Antibodies to thyroid peroxidase & Negative & & Negative \\
\hline Antibodies to gastric parietal cells & Negative & & Negative \\
\hline Antibodies to pancreatic islet cells & Negative & & Negative \\
\hline Antinuclear antibodies & $1: 160$ (fine-speckled) & & $<1: 20$ \\
\hline Antibodies to extractable nuclear antigens & Negative & & Negative \\
\hline Antibodies to mitochondria & Negative & & Negative \\
\hline Antibodies to liver/kidney microsomes & Negative & & Negative \\
\hline Antibodies to smooth muscle & Negative & & Negative \\
\hline Coombs'test & Negative & & Negative \\
\hline Cryoglobulinemia & Absent & & Absent \\
\hline Rheumatoid factor & Negative & & Negative \\
\hline
\end{tabular}

Tests were performed on patient's serum, if not otherwise specified.

Units for each parameter are given in the right-hand column: ${ }^{*}$ Repeated after 1 week. ${ }^{\dagger}$ Repeated after 8 weeks.

AST, aspartate aminotransferase: ALT, alanine aminotransferase; ALP, alkaline phosphatase; GGT, gamma glutamyltransferase; ATIII, antithrombin III; INR, international normalized ratio. 
Biochemical analyses performed on admission are shown in Table 1. A few days later the patient developed fatigue, arterial hypotension, increasing pulse rate and mental confusion, and abdominal pain was referred on both flank regions. A new abdominal CT scan showed a bilateral adrenal enlargement consistent with gland haemorrhage, which was larger at the left side (images not available). The patient was treated with electrolytes, antibiotics, oral corticosteroids (cortisone acetate, $25 \mathrm{mg} /$ day) and then transferred to our clinic to evaluate his adrenal function (August 2002). On physical examination the patient showed skin hyperpigmentation of sun-exposed areas (possible related only to sun-tanning), but not to oral mucosa or nipples. Arterial blood pressure was low $(85 / 60 \mathrm{mmHg})$, despite previous infusion of electrolytes.

The hypothesis of a primary hypoadrenalism was confirmed by the detection of low cortisol and high corticotrophin plasma values (Table 1). Plasma levels of dehydroepiandrosterone sulphate (DHEA-S) were markedly reduced. By contrast, plasma aldosterone was initially in the lower limits of the normal range together with a normal renin activity, although it later became greatly reduced and upright renin activity increased (Table 1). Urinary catecholamines were normal. Three consecutive blood cultures and Treponema pallidum haemoagglutination test were negative. Blood coagulation tests revealed a slightly increased prothrombin time, but activated partial thromboplastin time was consistently elevated on repeated occasions, together with diluted Russell's-venom-viper time and kaolin-clotting time. Anti-thrombin III, protein $\mathrm{C}$ and protein $\mathrm{S}$ plasma levels were normal, and the search for activated protein $\mathrm{C}$ resistance was negative. Anticardiolipin antibodies of the IgM class were positive at high titre (Table 1). These findings were all confirmed 8 weeks later. On that occasion nuclear magnetic resonance (NMR) imaging showed an increased volume in both adrenal glands (left, $4 \mathrm{~cm}$; right, $2 \mathrm{~cm}$; Fig. 1B). Antinuclear antibody investigation revealed a positive staining by indirect immunofluorescence on Hep-2 cells with fine-speckled pattern, but antibodies to extractable nuclear antigens and native DNA by enzyme immune assay (EIA) were negative. Antibodies to adrenal cortex, 21-hydroxylase, neutrophil cytoplasm, red blood cells, platelets, thyro-peroxidase and thyroglobulin were negative. Thyroid function and imaging were normal. Chest radiography and tubercolin test were normal and the patient had no history of tuberculous infection. Ultrasound examination of lower limbs did not reveal signs of recent venous thrombosis and heart ultrasound study ruled out the presence of cardiac valve thickening or vegetations. Colour Doppler ultrasound of carotid arteries was normal. The fundus oculi evaluation excluded a thrombosis of the central retinal vein. Based on patient's medical history, clinical and laboratory findings we formulated the diagnosis of PAPS.
A treatment with intravenous hydrocortisone was started promptly, resulting in progressive improvement of clinical conditions. The patient was thus treated with warfarin at a dose to maintain international normalized ratio (INR) range between 2.5 and 3 together with cortisone acetate at $37.5 \mathrm{mg} /$ day. Since his discharge from our clinic he has not experienced any other clinical symptom or sign suggestive of vascular secondary thrombosis and has been continuing treatment. The patient was subsequently revaluated with abdominal CT and NMR scans which still showed bilaterally enlarged adrenal glands (left mainly), although reduced compared with previous evaluations, with haemorrhage residues (Fig. 1C and D).

\section{Background review}

We performed a computer-assisted search of the literature to identify cases with definite primary adrenal insufficiency and PAPS. The research was carried out from 1988 (when the association between APS and Addison's disease was first reported) $(9,10)$ through January 2005. The main search keywords were Addison's disease, adrenal failure, hypoadrenalism, adrenal haemorrhage, adrenal thrombosis, APS, lupus anticoagulant and anticardiolipin antibodies. We considered exclusively clinical cases with unambiguous and welldocumented diagnosis of Addison's disease related to PAPS, usually resulting from bilateral adrenal haemorrhagic infarction. Patients who developed adrenal failure after a clear-cut diagnosis of PAPS were not included in order to rule out adrenal haemorrhage possibly favoured by anticoagulant therapy. 19 cases met the criteria for inclusion. Age, gender, possible precipitating factors or previous unexplained major thrombotic events, and endocrine and immunologic features were considered.

Table 2 summarizes clinical and main laboratory characteristics of patients with PAPS heralding with acute adrenal failure, including the present report. There were 15 males (including the one from this case study) and 5 females. The mean age of the patients was $41.6 \pm 20.5$ years (range $10-70$ years). Abdominal pain was present in 14 patients $(70 \%)$, followed by fever (13 patients) and hypotension (12 patients). In one patient adrenal failure was a component of a catastrophic syndrome (patient no. 9). In eight patients there was a recognized precipitating factor which contributed to the onset of adrenal insufficiency: three underwent surgical procedures, four had infections and one had trauma from physical exertion. Two patients reported previous 'idiopathic' manifestations of vascular thrombosis that were not apparently related to APS. The main CT or NMR imaging findings were consistent with bilateral adrenal haemorrhage (11 patients) or infarction (three patients). In one patient adrenals were described as normal, in two patients 
Table 2 Clinical manifestations, adrenal imaging, laboratory and immunologic features of 20 patients with adrenal failure as first-recognized manifestation in PAPS Cases were reported in chronological order of description.

\begin{tabular}{|c|c|c|c|c|c|c|c|c|c|c|c|c|c|}
\hline $\begin{array}{l}\text { Patient } \\
\text { (Reference) }\end{array}$ & Sex & $\begin{array}{l}\text { Age at } \\
\text { onset } \\
\text { (years) }\end{array}$ & $\begin{array}{l}\text { Major symptoms at } \\
\text { diagnosis of Addison's } \\
\text { disease }\end{array}$ & $\begin{array}{l}\text { Precipitating } \\
\text { factors(s) }\end{array}$ & $\begin{array}{l}\text { Previous } \\
\text { unexplained } \\
\text { thrombotic events }\end{array}$ & $\begin{array}{l}\text { Adrenal CT/NMR } \\
\text { imaging }\end{array}$ & $\begin{array}{l}\text { ACTr } \\
(\mathrm{pM})\end{array}$ & Cortisol (nM) & Aldosterone (pM) & $\begin{array}{l}\text { DHEA- } \\
S(\mu \mathrm{M})\end{array}$ & ACA & LAC & $\begin{array}{l}\text { ACL- } \\
\text { Abs }\end{array}$ \\
\hline $1(17)$ & $\mathrm{F}$ & 10 & Tiredness, hypotension & $\begin{array}{l}\text { Pneumonia } \\
\text { and pleurisy }\end{array}$ & - & n.r. & n.r. & $\begin{array}{l}\text { (No } \\
\text { response } \\
\text { to ACTH) }\end{array}$ & n.r. & n.r. & - & + & $\lg G, M$ \\
\hline $2(18)$ & M & 42 & $\begin{array}{l}\text { Abdominal pain, } \\
\text { lethargy, hypotension }\end{array}$ & - & - & $\begin{array}{l}\text { Enlarged right } \\
\text { adrenal }\end{array}$ & 64 & 89 & n.r. & n.r. & - & + & n.r. \\
\hline $3(19)$ & M & 34 & Abdominal pain, fever & $\begin{array}{l}\text { Playing } \\
\text { squash }\end{array}$ & $\begin{array}{l}\text { Lower limb DVT } \\
\text { at } 17 \text { years }\end{array}$ & n.r. & n.r. & 50 & n.r. & n.r. & - & + & + \\
\hline $4(14)$ & M & 20 & $\begin{array}{l}\text { Abdominal pain, fever, } \\
\text { hypotension }\end{array}$ & - & $\begin{array}{l}\text { Femoral artery } \\
\text { thrombosis }\end{array}$ & $\begin{array}{l}\text { Bilateral adrenal } \\
\text { haemorrhage }\end{array}$ & n.r. & $<25$ & n.r. & n.r. & n.r. & + & n.r. \\
\hline $5(20)$ & $\mathrm{F}$ & 15 & Not reported & - & - & n.r. & n.r. & n.r. & n.r. & n.r. & - & + & $\lg M, G$ \\
\hline $6(21)$ & M & 71 & $\begin{array}{l}\text { Fatigue, fever, } \\
\text { hypotension, weight loss }\end{array}$ & - & - & $\begin{array}{l}\text { Bilateral adrenal } \\
\text { haemorrhage }\end{array}$ & 209 & 85 & $<20$ & n.r. & n.r. & + & $\lg G$ \\
\hline 7 (22) & M & 10 & $\begin{array}{l}\text { Abdominal pain, fever, } \\
\text { vomiting }\end{array}$ & - & - & $\begin{array}{l}\text { Bilateral adrenal } \\
\text { infarction }\end{array}$ & n.r. & 33 & Undetectable & n.r. & n.r. & + & n.r. \\
\hline $8(23)$ & $\mathrm{F}$ & 50 & $\begin{array}{l}\text { Chest pain, fever, } \\
\text { hypotension }\end{array}$ & $\begin{array}{l}\text { Gynaecologic } \\
\text { surgery }\end{array}$ & - & $\begin{array}{l}\text { Bilateral adrenal } \\
\text { haemorrhage }\end{array}$ & 88 & 90 & n.r. & n.r. & - & n.r. & $\lg G, M$ \\
\hline $9 *(24)$ & M & 57 & $\begin{array}{l}\text { Abdominal pain, fever, } \\
\text { hypotension }\end{array}$ & - & - & $\begin{array}{l}\text { Bilateral adrenal } \\
\text { infarction }\end{array}$ & n.r. & Undetectable & n.r. & n.r. & n.r. & + & $\lg G$ \\
\hline $10(25)$ & M & 51 & $\begin{array}{l}\text { Fever, left-sided chest } \\
\text { pain }\end{array}$ & $\begin{array}{l}\text { Abdominal } \\
\text { surgery }\end{array}$ & - & $\begin{array}{l}\text { Bilateral adrenal } \\
\text { haemorrhage }\end{array}$ & 97 & 20 & Low urinary & n.r. & - & + & $\lg G$ \\
\hline $11(26)$ & M & 61 & Abdominal pain, fever & - & - & $\begin{array}{l}\text { Bilateral adrenal } \\
\text { haemorrhage }\end{array}$ & 21 & n.r. & n.r. & n.r. & n.r. & + & $\lg G, M$ \\
\hline $12(27)$ & M & 70 & $\begin{array}{l}\text { Abdominal pain, } \\
\text { hypotension }\end{array}$ & - & - & $\begin{array}{l}\text { Bilateral adrenal } \\
\text { haemorrhage }\end{array}$ & 66 & 20 & n.r. & n.r. & n.r. & + & $\lg G$ \\
\hline $13+(28)$ & $\mathrm{F}$ & 45 & $\begin{array}{l}\text { Left flank pain, fever, } \\
\text { hypotension }\end{array}$ & - & - & $\begin{array}{l}\text { Bilateral adrenal } \\
\text { haemorrhage }\end{array}$ & n.r. & 85 & $<140$ & n.r. & n.r. & + & + \\
\hline $14 †(29)$ & $\mathrm{F}$ & 33 & Abdominal pain, vomiting & ARDS & - & $\begin{array}{l}\text { Bilateral adrenal } \\
\text { haemorrhage }\end{array}$ & n.r. & 30 & n.r. & n.r. & n.r. & + & $\lg G$ \\
\hline $15(30)$ & M & 30 & $\begin{array}{l}\text { Abdominal pain, fever, } \\
\text { hypotension }\end{array}$ & Renal biopsy & - & $\begin{array}{l}\text { Bilateral adrenal } \\
\text { infarction }\end{array}$ & n.r. & $<20$ & n.r. & n.r. & n.r. & + & - \\
\hline $16(11)$ & M & 60 & Weakness, hypotension & - & - & $\begin{array}{l}\text { Normal } \\
\text { (intaparenchymal } \\
\text { microhaemorrhages?) }\end{array}$ & 24 & 110 & $\begin{array}{l}\text { Lower limits of the } \\
\text { normal range } \\
\text { (urine) }\end{array}$ & n.r. & n.r. & + & $\lg G, M$ \\
\hline $17(16)$ & M & 59 & $\begin{array}{l}\text { Abdominal pain, fever, } \\
\text { hypotension }\end{array}$ & $\begin{array}{l}\text { Right arm } \\
\text { cellulitis }\end{array}$ & - & $\begin{array}{l}\text { Bilateral adrenal } \\
\text { haemorrhage }\end{array}$ & n.r. & 30 & $<20$ & n.r. & n.r. & + & $\lg G, M$ \\
\hline $18(31)$ & M & 10 & $\begin{array}{l}\text { Right flank pain, fever, } \\
\text { hypotension }\end{array}$ & - & - & $\begin{array}{l}\text { Enlarged edematous } \\
\text { right adrenal }\end{array}$ & 47 & 62 & 20 & 0.08 & n.r. & + & $\lg G, M$ \\
\hline $19(32)$ & M & 42 & $\begin{array}{l}\text { Thoracic and abdominal } \\
\text { pain, fatigue }\end{array}$ & & - & $\begin{array}{l}\text { Bilateral adrenal } \\
\text { haemorrhage }\end{array}$ & 250 & n.r. & n.r. & n.r. & n.r. & + & $\lg G, M$ \\
\hline 20 (p.c.) & M & 63 & $\begin{array}{l}\text { Abdominal pain, fever, } \\
\text { hypotension }\end{array}$ & Colecistitis? & - & $\begin{array}{l}\text { Bilateral adrenal } \\
\text { haemorrhage }\end{array}$ & 53 & 133 & $80<-60$ & 0.3 & - & + & $\lg M$ \\
\hline
\end{tabular}

All values were reported for plasma levels according to Standard International (SI) units. Conventional units were converted accordingly.

CT/NMR, computed tomography/nuclear magnetic resonance; ACTH, adrenocorticotrophin hormone; DHEA-S, dehydroepiandrosterone sulphate; ACA, adrenal cortex autoantibodies; LAC, lupus anticoagulant; ACL-Abs, anticardiolipin antibodies; p.c. = present case; n.r. = not reported; DVT = deep venous thrombosis; ARDS = acute respiratory distress syndrome. ${ }^{* C a t a s t r o p h i c ~ A P S . ~}$ †Associated with Hashimoto's thyroiditis. 
only one gland was found to be involved (the right), whereas in three patients imaging descriptions were not reported. Baseline cortisol plasma levels were decreased with respect to the inner reference values in all the 17 tested patients. Aldosterone was low in seven of the eight evaluated patients, whereas in one patient urine aldosterone was within the lower limits of the normal range. In our patient, both plasma aldosterone and renin activity were initially in the normal ranges, but later plasma aldosterone levels were clearly low and renin activity was high (Table 1). DHEA-S was markedly reduced in both the two investigated patients. Adrenal cortex autoantibodies were negative in all of seven patients, whereas at diagnosis of adrenal insufficiency lupus anticoagulant was detectable in 19 of the 20 tested. Anticardiolipin antibodies of both IgG and IgM isotypes were found in eight patients, of the IgG or the IgM isotype alone in six, and they were not specified in one and not reported in five patients (Table 2).

\section{Discussion}

APS is characterized by the presence of both venous and arterial recurrent thrombotic events associated with the repeated detection of antibodies directed against phospholipid-protein complexes. APS may be associated with another autoimmune disease (secondary APS), or unrelated to an underlying disease (PAPS) (6-8). Among the unusual manifestations of APS, adrenal insufficiency appears undoubtedly rare, and despite the stronger prevalence of APS in women $(82 \%)$ the prevalence of adrenal involvement is higher in men $(55 \%)(3,5)$. This male preponderance becomes much more evident if we consider adrenal failure as the heralding manifestation of a PAPS, males being $75 \%$ of the cases described so far.
In the present report, adrenal failure was the first established clinical manifestation of APS and no other underlying autoimmune diseases were detected, so criteria for a diagnosis of PAPS were fulfilled. Bilateral adrenal haemorrhage shown by our patient appeared to be the first expression of a hypercoagulable state due to the APS and was not a side effect of anticoagulant drugs, as suggested previously for some patients $(11,12)$, since treatment was started after the diagnosis of APS with adrenal haemorrhage had been made. Because adrenal cortex autoantibodies and tubercolin skin test were negative we ruled out other more common causes of primary adrenal insufficiency.

The pathogenic mechanism leading to hypoadrenalism in APS is probably related to adrenal veins thrombosis and consequent haemorrhagic infarction. The peculiar pattern of vascular anatomy of the adrenals with a rich arterial supply, but a limited venous drainage by a single vein, may favour the development of haemorrhagic infarction. Adrenal blood supply derives from three main supra-renal arteries that pierce the gland surface, dividing into 50-60 small branches and forming a subcapsular plexus which embraces the cell clusters in the zona glomerulosa and then run among the cellular cords in the zona fasiculata. The capillary branching from the arterial system forms a microvascular network around the zona reticularis which drains into the medullary sinusoids by relatively few small venules that eventually form a large central vein (Fig. 2). This transition from artery to capillary system is so sharp that it forms a sort of functional 'vascular dam' (13). In addition, medullary veins show an eccentric musculature which favours the development of pouches of local stasis when bundles contract, and vein contraction is promoted by the high catecholamine concentration at this level. Therefore, a progressive increase in arterial blood pressure during vein thrombosis may lead to intragland-

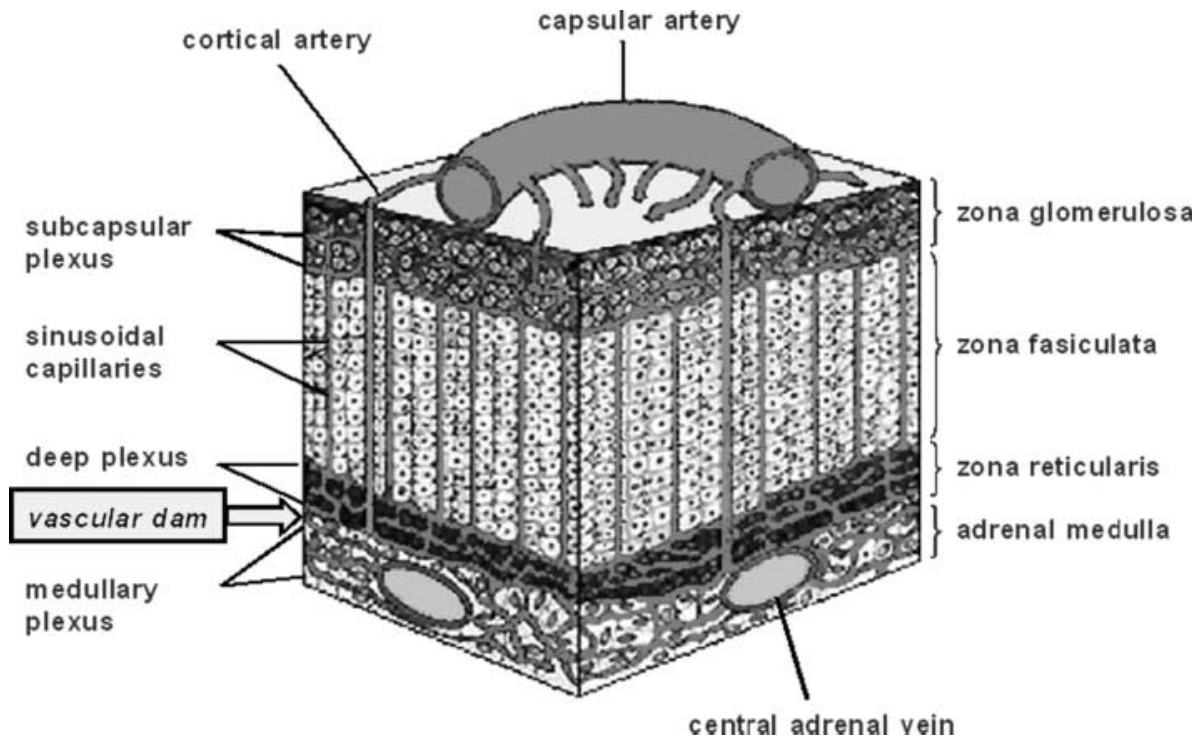

Figure 2 Adrenal circulation illustrating the brusque transition from arterial to capillary circulation with the 'vascular dam' that may predispose to adrenal haemorrhage when thrombosis of the central adrenal vein occurs. Modified from http://medic.med.uth.tmc. edu/edprog/histolog/endo/ hist-09a.htm, with permission. 
ular haemorrhage $(13,14)$. Adrenal glands are highly susceptible to haemorrhagic damages, including anticoagulant therapy and other haemorrhagic diathesis like septicemia (e.g. Waterhouse-Fridericksen fulminant meningococcaemia), disseminated intravascular coagulopathy, abdominal traumas, post-surgical periods or severe systemic illness. Most of the time adrenal involvement in APS by thrombosis/haemorrhage is bilateral, but not infrequently it occurs at different times, so the period elapsing from the haemorrhagic event to acute adrenal failure may be crucial to achieve a correct diagnosis. In two previous case reports with adrenal insufficiency only the right gland appeared to be involved $(18,31)$, probably because it is constricted between the liver and the right kidney, while in another case both the adrenals looked normal (11). Therefore, it cannot be excluded that sometimes intraparenchymal microhaemorrhages may not be recognized by CT or NMR, but are able to compromise adrenal function as well.

Interestingly, considering those patients in whom DHEA-S, cortisol and aldosterone plasma levels were measured (patient no. 18 and present report), it was found that hormones produced by the zona reticularis and the zona fasiculata are those first compromised by adrenal haemorrhage, whereas the zona glomerulosa appears, at least in the beginning, relatively spared. This is also suggested by the observation that our patient had normal plasma and urine aldosterone levels at first examination and that only in a following phase were they noticeably reduced. This centrifugal progression of adrenal-failure impairment is consistent with a thrombosis of the central adrenal vein(s) as the initiating event of the cascade leading to gland haemorrhage. This way of presentation of adrenal failure is considerably different from that observed in classical autoimmune Addison's disease, where the first layer affected by the immune-mediated destruction is usually the mineralcorticoid compartment (2). This is possibly due to the fact that the zona glomerulosa is thinner compared with the other layers or, alternatively, is more vulnerable to the autoimmune attack advancing with blood flow (centripetal progression of adrenal failure). However, it must be kept in mind that multiple autoimmune disorders may coexist in the same patient. Gonzáles et al. (15) first reported a case of a middleaged woman with APS and adrenal insufficiency, but normal adrenals on CT scan, who also had Hashimoto's thyroiditis and premature ovarian failure (15). This patient was likely affected by Schmidt's syndrome and APS, although adrenal cortex antibodies were unfortunately not determined.

In most of the reported cases, including the present one, adrenal haemorrhage was discovered serendipitously on CT performed for other reasons. In $40 \%$ of the patients a stressful precipitating event unveiled adrenal failure and fever, usually related to acute infections, was the prominent accompanying symptom of adrenal insufficiency. A Waterhouse-Friederichsen- like syndrome should always be considered in differential diagnosis, but it predominantly occurs in childhood and blood cultures generally confirm bacterial septicaemia (16).

As exemplified by our case report, the diagnosis of adrenal haemorrhage may be overlooked and a bilateral adrenal involvement may result in a worrying and life-threatening Addisonian crisis. Therefore, a prolongation of the activated partial thromboplastin time at routine blood tests in patients with adrenal insufficiency should always encourage the endocrinologist to look systematically for the presence of antiphospholipid antibodies.

\section{References}

1 Arlt W \& Allolio B. Adrenal insufficiency. Lancet 2003361 1881-1893.

2 Betterle C, Dal Pra C, Mantero F \& Zanchetta R. Autoimmune adrenal insufficiency and autoimmune polyendocrine syndromes: autoantibodies, autoantigens, and their applicability in diagnosis and disease prediction. Endocrine Reviews 200223 327-364.

3 Espinosa G, Santos E, Cervera R, Piette J-C, de la Red G, Gil V, Font J, Couch R, Ingelmo M \& Asherson RA. Adrenal involvement in the antiphospholipid syndrome. Clinical and immunologic characteristics of 86 patients. Medicine 200382 106-118.

4 Asherson RA, Cervera R, Piette J-C, Shoenfeld Y, Espinosa G, Petri MA, Lim E, Law TC, Gurjal A, Jedryka-Goral A, Chwalinska-Sadowska H, Dibner RJ, Rojas-Rodriguez J, GarciaCarrasco M, Grandone JT, Parke AL, Barbosa P, Vasconcelos C, Ramos-Casals M, Font J \& Ingelmo M. Catastrophic antiphospholipid syndrome. Clues to the pathogenesis from a series of 80 patients. Medicine (Baltimore) $200180355-377$.

5 Euro-Phospholipid Project Group. Antiphospholipid syndrome. Clinical and immunologic manifestations and patterns of disease expression in a cohort of 1,000 patients. Arthritis \& Rheumatism 200246 1019-1027.

6 Levine JS, Branch DW \& Rauch J. The antiphospholipid syndrome. New England Journal of Medicine 2002346 752-763.

7 Mackworth-Young CG. Antiphospholipid syndrome: multiple mechanisms. Clinical and Experimental Immunology 2004136 393-401.

8 Asherson RA. A 'primary' antiphospholipid syndrome. Journal of Rheumatology $1988151742-1746$.

9 Grottolo A, Ferrari V, Mariano M, Zambruni A, Tincani A \& Del Bono R. Primary adrenal insufficiency, circulating lupus anticoagulant and anticardiolipin antibodies in a patient with multiple abortion and recurrent thrombotic episodes. Haematologica 198873 517-519.

10 Asherson RA \& Hughes GR. Recurrent deep vein thrombosis and Addison's disease in primary antiphospholipid syndrome. Journal of Rheumatology $198916378-380$.

11 Satta MA, Corsello SM, Della Casa S, Rota CA, Pirozzi B, Colasanti S, Cina G, Grossman AB \& Barbarino A. Adrenal insufficiency as the first clinical manifestation of the primary antiphospholipid antibody syndrome. Clinical Endocrinology 200052 $123-126$.

12 McCroskey RD, Phillips A, Mott F \& Williams EC. Antiphospholipid antibodies and adrenal haemorrhage. American Journal of Haematology 199136 60-62.

13 Fox B. Venous infarction of the adrenal glands. Journal of Pathology $197611965-89$.

14 Rao H, Vagnucci AH \& Amico JA. Bilateral massive adrenal haemorrhage: early recognition and treatment. Annals of Internal Medicine $1989110227-235$ 
15 Gonzáles G, Gutièrrez M, Ortiz M, Tellez R, Figueroa F \& Jacobelli S. Association of primary antiphospholipid syndrome with primary adrenal insufficiency. Journal of Rheumatology $1996231286-1287$.

16 Vella A, Nippoldt TD \& Morris JC III. Adrenal haemorrhage: a 25year experience at the Mayo Clinic. Mayo Clinic Proceedings 2001 $76161-168$.

17 Pelkonen P, Simell O, Rasi V \& Vaarala O. Venous thrombosis associated with lupus anticoagulant and anticardiolipin antibodies. Acta Paediatrica Scandinavica 198877 767-772.

18 Yap AS, Powell EE, Yelland CE, Mortimer RH \& Perry-Keene DA. Lupus anticoagulant. Annals of Internal Medicine 1989111 262-263.

19 Carette S \& Jobin F. Acute adrenal insufficiency as a manifestation of the anticardiolipin syndrome? A case report. Annals of the Rheumatic Diseases $1989 \mathbf{4 8} 430-431$.

20 Rose C \& Goldsmith DP. Childhood adrenal insufficiency, chorea, and antiphospholipid antibodies. Annals of the Rheumatic Diseases $199049421-422$.

21 Siu SCB, Kitzman DW, Sheedy PF II \& Northcutt RC. Adrenal insufficiency from bilateral adrenal haemorrhage. Mayo Clinic Proceedings $199065664-670$.

22 Inam S, Sidki K, Al-Marshedy AR \& Judzewitsch R. Addison's disease, hypertension, renal and hepatic microthrombosis in 'primary' antiphospholipid syndrome. Postgraduate Medical Journal $199167385-388$.

23 Komesaroff PA, Yung AP \& Topliss DJ. Postoperative primary adrenal failure in a patient with anticardiolipin antibodies. Journal of Rheumatology $1991 \mathbf{1 8} 88-90$.

24 Pérez RA, McClendon JR \& Lie JT. Primary antiphospholipid syndrome with multiorgan arterial and venous thromboses. Journal of Rheumatology $1992191289-1292$.

25 Papadopoulos KI, Jönsson A, Berntorp E, Törnquist C \& Hulthén UL. Primary antiphospholipid syndrome associated with postoperative primary adrenal failure. Journal of Internal Medicine 1995238 175-178.

26 Luppi M, Marasca R, Torricelli P, Leonardi G, Gavioli GL, Bocchi A \& Torelli G. Spontaneous adrenal gland haematoma in a patient with antiphospholipid antibodies. European Journal of Haematology $199555335-338$.

27 Marie I, Levesque H, Heron F, Cailleux N, Borg JY \& Courtois H. Acute adrenal failure secondary to bilateral infarction of the adrenal glands as the first manifestation of primary antiphospholipid syndrome. Annals of the Rheumatic Diseases $1997 \mathbf{5 6}$ 567-568.

28 Caron P, Chabannier MH, Cambus JP, Fortenfant F, Otal P \& Suc JM. Definitive adrenal insufficiency due to bilateral adrenal haemorrhage and primary antiphospholipid syndrome. Journal of Clinical Endocrinology and Metabolism $1998 \mathbf{8 3}$ 1437-1439.

29 Argento A \& Di Benedetto RJ. ARDS and adrenal insufficiency associated with the antiphospholipid antibody syndrome. Chest $19981131136-1138$.

30 Jose MD, Bannister KM, Clarkson AR \& Faull RJ. Renal biopsy precipitating catastrophic antiphospholipid syndrome, complicated by protein $\mathrm{S}$ deficiency and acute adrenal failure. Australian and New Zealand Journal of Medicine 199929 105-106.

31 Böber E, Kovanlikaya A \& Büyükgebiz A. Primary antiphospholipid syndrome: an unusual case of adrenal insufficiency. Hormone Research 200156 140-144.

32 Berneis K, Buitrago-Téllez C, Müller B, Keller U \& Tsakiris DA. Antiphospholipid syndrome and endocrine damage: why bilateral adrenal thrombosis? European Journal of Haematology $200371299-302$.

Received 19 April 2005

Accepted 8 July 2005 